\title{
PENGARUH MODEL PEMBELAJARAN BERBASIS MASALAH TERHADAP HASIL BELAJAR FISIKA SISWA KELAS X SMAN 2 PRAYA TAHUN PELAJARAN 2015/2016
}

\author{
Nuning Apriani, Syahrial Ayub, Hikmawati \\ Program Studi Pendidikan Fisika FKIP, Universitas Mataram, Indonesia \\ Email: hikmawati.fkip@unram.ac.id
}

\begin{abstract}
Abstrak - Penelitian ini bertujuan untuk mengetahui pengaruh model pembelajaran berbasis masalah terhadap hasil belajar fisika siswa kelas X SMAN 2 Praya tahun pelajaran 2015/2016. Jenis penelitian ini adalah penelitian eksperimen dengan desain penelitian post-test only group design. Populasi dari penelitian ini adalah semua siswa kelas X SMAN 2 Praya Tahun Ajaran 2015/2016 berjumlah 400 orang. Pengambilan sampel penelitian menggunakan teknik cluster random sampling, sehingga diperoleh kelas X 4 sebagai kelas eksperimen dan kelas X 6 sebagai kelas kontrol. Instrumen penelitian yang digunakan adalah tes multiple choice dengan lima alternatif jawaban. Hipotesis Penelitian diuji menggunakan $t$-test polled varians, diperoleh $t_{\text {hitung }}$ sebesar 3,42 dan $t_{\text {tabel }}$ sebesar 1,99 pada taraf signifikansi $5 \%$. Oleh karena $t_{\text {hitung }}>t_{\text {tabel }}$, maka Ho ditolak dan Ha diterima. Jadi, dapat disimpulkan bahwa terdapat pengaruh model pembelajaran berbasis masalah terhadap hasil belajar fisika siswa kelas X SMAN 2 Praya tahun pelajaran 2015/2016.
\end{abstract}

Kata kunci: model pembelajaran berbasis masalah, hasil belajar.

Abstract - The purpose of this study was to investigate the influence of problem based learning model toward physics learning outcomes at SMAN 2 Praya grade X at the academic year 2015/2016. This study was experiment with post-test only control group design. The population of this study were all students of $\mathrm{X}^{\text {th }}$ grade with number of students were 400 students. Cluster random sampling was used to choose the class sample with X-4 as experiment class and X-6 as control class. The instrument of this study used multiple choise test with 5 alternative answer. Based from the result, data were analyzed using t-test polled varians. The data obtained 3.42 for the t-hint and 1.99 for the t-table with significant level 5\%. Therefore $\mathrm{t}$-hint $>\mathrm{t}$-table, the $\mathrm{H}_{0}$ rejected and $\mathrm{H}_{\mathrm{a}}$ be accepted. This result shows that problem based learning model is influencing the stuent's physics academy result at SMAN 2 Praya $\mathrm{X}^{\text {th }}$ grade academic year 2015/2016.

Keywords: Problem based learning model, learning outcomes.

\section{PENDAHULUAN}

Pendidikan memiliki peranan yang sangat penting dalam meningkatkan sumber daya manusia. UndangUndang Sistem Pendidikan Nasional (sisdiknas) mislanya, menunjukkan akan peran strategis pendidikan dalam pembentukan sumber daya yang berkualitas[1]. Selain itu itu, Undang-Undang Sistem Pendidikan Nasional No 20 Tahun 2003 telah merumuskan fungsi pendidikan nasional. Untuk mencapai tujuan pendidikan tersebut, tentu tidak terlepas dari proses belajar mengajar. Proses belajar mengajar terjadi karena adanya intraksi antara peserta didik dengan pendidik dan sumber belajar pada suatu lingkungan belajar[2].

Proses belajar mengajar tersebut meliputi setiap mata pelajaran, salah satunya yaitu IPA atau sains. Pada hakekatnya Ilmu Pengetahuan Alam (IPA) merupakan suatu produk, proses, dan sikap. Fisika merupakan bagian dari IPA maka dapat diambil persepsi bahwa hakikat fisika sama dengan hakikat IPA. Setiono [2] menyatakan bahwa fisika merupakan ilmu pengetahuan yang memiliki karakteristik yang berbeda dibandingkan dengan ilmu pengetahuan yang lain. Oleh karena itu, proses belajar mengajar Fisika di sekolah juga menyesuaikan dengan karakteristik tersebut. Fisika meliputi tiga karakteristik, yaitu: pengetahuan, proses, dan sikap ilmiah. Pengetahuan dalam Fisika berupa produk (hasil) meliputi konsep, prinsip, hukum, dan teori. Sedangkan proses dalam Fisika berkaitan dengan keterampilan dalam menemukan pengetahuan tentang fisika sehingga keaktifan siswa dalam pembelajaran menjadi sangat penting.

Secara umum, hasil belajar yang dicapai siswa dipengaruhi oleh dua faktor utama yaitu faktor eksternal dan faktor internal. Faktor internal adalah faktor yang berasal dari dalam diri siswa tersebut, antara lain jasmani dan rohani. Sedangkan faktor eksternal yaitu faktor yang datang dari luar diri siswa yaitu berupa faktor lingkungan. Sementara itu, faktor yang mempengaruhi hasil belajar siswa secara khusus yaitu kurangnya motivasi siswa dalam belajar, media pembelajaran yang kurang lengkap dalam menunjang pembelajaran siswa, penggunaan media pembelajaran yang kurang tepat, kebiasaan belajar, ketekunan, 
kurangnya melaksanakan percobaan dan demonstrasi [3].

Faktanya, pembelajaran fisika yang terjadi biasanya cenderung didominasi guru (teacher center) hal ini yang menyebabkan siswa menjadi pasif dalam proses belajar mengajar. Siswa hanya memperhatikan penjelasan guru dan menghafal apa yang diajarkan guru tanpa ada timbal balik dari siswa. Trianto [4] berpendapat bahwa siswa hanya menghapal konsep dan kurang menggunkan konsep tersebut jika menemui masalah dalam kehidupan nyata. Selama ini orientasi pembelajaran masih bersifat teacher center bukan student center sehingga kurang mampu merangsang siswa untuk terlibat aktif dan mengeleluarkan ide-ide atau menunjukkan kemampuan berfikir dalam proses pembelajaran.

Menurut Rusman [5] guru harus menggunakan model pembelajaran yang akan membuat siswa menjadi lebih mandiri dalam pembelajaran. Wijaya [6] menyatakan bahwa pembelajaran berbasis masalah, adalah salah satu model pembelajaran yang dasar filosofisnya adalah konstruktivisme yakni pengetahuan itu akan tumbuh berkembang melalui pengalaman. Secara garis besarnya, prinsip konstruktivis adalah: (1) pengetahuan di bangun oleh siswa sendiri, baik secara individu maupun sosial, (2) pengetahuan tidak dapat dipindahkan dari guru ke siswa, kecuali dengan keaktifan siswa sendiri untuk menalar, (3) siswa aktif mengkontruksi terus menerus, sehingga terjadi perubahan konsep yang lebih rinci lengkap serta sesuai dengan konsep ilmiah, dan (4) guru berfungsi untuk membantu menyediakan sarana dan situasi agar proses konstruksi siswa berjalan mulus.

\section{Model Pembelajaran Brbasis Masalah}

Model pembelajaran berbasis masalah merupakan sebuah model pembelajaran yang menyediakan pengalaman autentik yang mendorong siswa untuk belajar aktif, mengkonstruksi pengetahuan, dan mengintegrasikan konteks belajar di sekolah dan belajar di kehidupan nyata secara alamiah $[7,8]$. Setyowati [9] juga menyatakan bahwa model pembelajaran berbasis masalah merupakan model pembelajaran yang dimulai dari pemberian masalah dalam kehidupan nyata, lalu dari masalah ini, siswa akan dirangsang untuk mempelajari masalah berdasarkan pengetahuan dan pengalaman yang telah mereka miliki sebelumnya sehingga akan terbentuk pengetahuan dan pengalaman baru. Masalah yang diberikan ini digunakan untuk mengikat siswa pada rasa ingin tahu pada pembelajaran yang dimaksud. Masalah diberikan, sebelum siswa mempelajari konsep atau materi yang berkenaan dengan masalah yang harus dipecahkan.

Model pembelajaran berbasis masalah didefinisikan sebagai rangkaian aktivitas pembelajaran yang menekankan pada proses penyelesaian masalah secara ilmiah. Model pembelajaran berbasis masalah mengusung gagasan utama bahwa tujuan pembelajaran dapat tercapai jika kegiatan pendidikan dipusatkan pada tugas-tugas atau permasalahan yang autentik, relevan, dan dipresentasikan dalam suatu konteks. Dengan kata lain, tujuan utama pendidikan adalah memecahkan masalah-masalah kehidupan. Konsekuensinya, bangunan pengetahuan maupun teori yang diajarkan tidak cukup hanya dihafal dan dipahami, melainkan harus dikaitkan dengan realita yang terjadi dan digunakan untuk menyelesaikan masalah-masalah yang ada [5].

Pembelajaran berbasis masalah memiliki beberapa karakteristik, Karakteristik PBM menurut Arends [10] diantaranya adalah (1) adanya driving question or problem (pengajuan pertanyaan atau masalah), (2) interdisciplinary focus (berfokus pada keterkaitan antar disiplin), (3) authentic investigation (penyelidikan autentika), (4) production of artifacts and exhibist (menghasilkan produk dalam bentuk karya nyata), (5) collaboration (kolaborasi).

Selain itu, pembelajaran berbasis masalah memiliki beberapa ciri ciri yang dikemukakan oleh Trianto [4] yaitu:

1) Pengajuan pertanyaan atau masalah yakni mengajukan situasi kehidupan nyata autentik, menghindari jawaban sederhana, dan memungkinkan adanya berbagai macam solusi untuk situasi tersebut.

2) Berfokus pada keterkaitan antar disiplin, artinya masalah yang akan diselidiki telah dipilih benar-benar nyata agar dalam pemecahannya dapat ditinjau dari berbagai mata pelajaran.

3) Penyelidikan autentik artinya mengharuskan siswa melakukan penyelidikan yang autentik untuk mencari penyelesaian nyata terhadap permasalahan nyata.

4) Menghasilkan produk-produk dan memamerkannya artinya pembelajaran berbasis masalah menuntut siswa untuk menghasilkan produk tertentu dalam bentuk karya nyata, artefak atau peragaan yang menjelaskan atau mewakili bentuk penyelesaian masalah yang mereka temukan.

5) Kolaborasi artinya model pembelajaran berbasis masalah dicirikan oleh siswa yang bekerja sama satu dengan yang lainnya. Paling sering secara berpasangan atau dalam kelompok kecil.

Model Pembelajaran berbasis masalah dapat meningkatkan keaktifan siswa dalam mengikuti proses 
pembelajaran karena selalu diberikan masalah yang harus diselesaikan di setiap pertemuan [11].

Sahidu [12] mengemukakan tentang langkahlangkah pembelajaran dalam penyelesaian masalah antara lain: 1) orientasi terhadap masalah. 2) mengorganisasi siswa untuk belajar. 3) membimbing penyelidikan individu maupun kelompok. 4) mengembangkan dan menyajikan hasil karya. 5) menganalisis dan mengevaluasi proses pemecahan masalah.

Tahapan pembelajaran pembelajaran berbasis masalah dipaparkan pada Tabel 1.

Tabel 1. Fase Pembelajaran berbasis masalah terhadap hasil belajar fisika siswa (Diadaptasi dari: Trianto [4])

\begin{tabular}{ll}
\hline \multicolumn{1}{c}{ Tahap } & \multicolumn{1}{c}{ Perilaku Guru } \\
\hline $\begin{array}{l}\text { Tahap 1: Memberikan orientasi tentang } \\
\text { permasalahannya kepada siswa }\end{array}$ & $\begin{array}{l}\text { Guru membahas tujuan pembelajaran, } \\
\text { menjelaskan logistik yang dibutuhkan, } \\
\text { mengajukan fenomena atau cerita untuk } \\
\text { memeunculkan masalah, memotivasi siswa untuk } \\
\text { terlibat dalam kegiatan pemecahan masalah. }\end{array}$ \\
\hline $\begin{array}{l}\text { Tahap 2: Mengorganisasikan siswa untuk } \\
\text { meneliti. }\end{array}$ & $\begin{array}{l}\text { Guru membantu siswa untuk mendefinisikan dan } \\
\text { mengorganisasikan tugas-tugas belajar terkait } \\
\text { dengan permasalahannya. }\end{array}$ \\
\hline $\begin{array}{l}\text { Tahap 3: Membimbing penyelidikan individual } \\
\text { maupun kelompok. }\end{array}$ & $\begin{array}{l}\text { Guru mendorong siswa untuk mendapatkan } \\
\text { informasi yang tepat, melaksanakan eksperimen }\end{array}$ \\
& dan mencari penjelasan dan solusi. \\
\hline $\begin{array}{l}\text { Tahap 4: Mengembangkan dan menyajikan } \\
\text { hasil karya }\end{array}$ & $\begin{array}{l}\text { Guru membantu siswa dalam merencanakan dan } \\
\text { menyiapkan hasil-hasil yang tepat, seperti laporan, } \\
\text { rekaman video dan model-model dan membantu } \\
\text { mereka untuk menyampaikan kepada orang lain. }\end{array}$ \\
\hline Tahap 5: Menganalisis dan mengevaluasi & $\begin{array}{l}\text { Guru membantu siswa untuk melakukan refleksi } \\
\text { proses pemecahan masalah. }\end{array}$ \\
& $\begin{array}{l}\text { merhadap investigasinya dan proses-proses yang } \\
\end{array}$ \\
\hline
\end{tabular}

\section{Hasil Belajar}

Hasil belajar adalah pola-pola perbuatan, nilainilai, pengertian-pengertian, sikap-sikap, apresiasi dan keterampilan. Menurut bloom, hasil belajar mencakup kemampuan kognitif, afektif, dan psikomotorik. Domain kognitif mencakup knowledge (pengetahuan, ingatan), comprehension (pemahaman, menjelaskan, meringkas, contoh), application (menerapkan), analysis (menguraikan, menentukan hubungan), synthesis (mengorganisasikan, merencanakan, membentuk bangunan baru), dan evaluation (menilai). Domain afektif mencakup receiving (sikap menerima), responding (memberikan respon), valuing (nilai), organization (organisasi), dan characterization (karakterisasi). Domain psikomotor meliputi initiatory, pre-routine, dan rountinized [13].

Hasil belajar pada penelitian ini mengacu pada taksonomi Bloom revisi, yakni pada ranah kognisi. Adapun ranah kognisi dalam revisi taksonomi Bloom yaitu mengingat, memahami, mengaplikasikan, menganalisis, mengevaluasi, dan mencipta [14]. Berikut dijelaskan mengenai keenam ranah kognisi di atas, yaitu sebagai berikut.
1. Mengingat: kemampuan untuk menyebutkan kembali informasi/pengetahuan yang tersimpan dalam ingatan.

2. Memahami: kemampuan memahami instruksi dan pengertian, makna, atau konsep yang telah diajarkan baik dalam bentuk lisan, tertulis, maupun grafik/diagram.

3. Mengaplikasikan: kemampuan melakukan sesuatu dan menerapkan pengetahuan dalam situasi tertentu.

4. Menganalisis: kemampuan menguraikan konsep menjadi beberapa bagian atau menghubungkan beberapa bagian untuk memperoleh pemahaman atas konsep secara utuh.

5. Mengevaluasi: kemampuan melakukan pertimbangan dengan menggunakan pengetahuan yang dimiliki untuk menyelesaikan kasus berdasarkan kriteria atau standar tertentu.

6. Mencipta: kemampuan memadukan unsur-unsur pengetahuan menjadi bentuk yang baru dan koheren.

\section{METODE PENELITIAN}

Jenis penelitian yang dilakukan adalah eksperimen. Untuk mengukur perbedaan yang timbul karena pengaruh perlakuan yang diberikan terhadap dua kelompok tersebut, dipilih bentuk desain kelompok 
kontrol post-test only control group design. Perlakuan yang diberikan pada setiap kelompok kelas dapat dilihat pada Tabel 2.

Tabel 2. Desain Penelitian

\begin{tabular}{lcc}
\hline \multicolumn{1}{r}{ Kelas } & Perlakuan & Post-test \\
\hline Eksperimen & $\mathrm{X}_{1}$ & $\mathrm{O}_{1}$ \\
Kontrol & $\mathrm{X}_{2}$ & $\mathrm{O}_{1}$ \\
\hline
\end{tabular}

Keterangan:

$\mathrm{O}_{1} \quad$ : pemberian post-test

$\mathrm{X}_{1}$ : pembelajaran dengan model

pembelajaran inkuiri terbimbing diintegrasikan dengan peer instruction

$\mathrm{X}_{2} \quad$ : pembelajaran dengan model

pembelajaran langsung metode ceramah

Penelitian ini dilakukan di SMAN 2 Praya dengan populasi seluruh siswa kelas $\mathrm{X}$ yang berjumlah 400 siswa dengan mengambil dua kelas sampel yaitu kelas X-4 sebagai kelas eksperimen dengan jumlah siswa 36 siswa dan kelas X-6 sebagai kelas kontrol dengan jumlah siswa 35 siswa.

Analisis data menggunakan uji-t polled varians pada taraf kesalahan 5\%. Analisis statistik diawali dengan uji normalitas data dan uji homogenitas data. Proses analisis data dibantu dengan program aplikasi Microsoft Excel 2010.

\section{HASIL DAN PEMBAHASAN}

Sebelum melakukan perlakuan terhadap kedua kelas, dilakukan uji coba instrument soal terhadap 40 soal pilihan ganda meliputi uji validitas, reliabilitas, uji daya beda, dan uji kesukaran. Setelah dilakukan tes uji coba terhadap instrumen, didapatkan 20 soal valid, 20 soal tidak valid untuk uji validitas. Sedangkan untuk uji reliabilitas terdapat 40 soal reliabel. Selanjutnya untuk analisis daya beda soal terdapat 6 soal dengan kriteria sangat baik, 9 soal dengan kriteria baik, 12 soal dengan kriteria cukup, 8 soal dengan kriteria jelek dan 5 soal dengan kriteria tidak baik. Untuk kriteria terakhir yaitu mengenai tingkat kesukaran soal, terdapat 2 soal dengan kategori baik sekali, 11 soal dengan kategori baik, 7 soal dengan aktegori cukup, 10 soal dengan kategori tidak baik, dan 10 soal dengan kategori tidak baik sekali. Setelah melakukan analisis terhadap isntrumen soal didapatkan 25 soal pilihan ganda yang dapat digunakan sebagai soal evaluasi pembelajaran fisika.

Pada pertemuan kelima dilakukan post-test pada kelas eksperimen dan kelas kontrol menggunakan 25 soal pilihan ganda. Data hasil post-test terlihat pada Tabel 3.

Tabel 3. Hasil Post-test Kelas Eksperimen dan Kontrol

\begin{tabular}{ccc}
\hline \multirow{2}{*}{ Nilai } & \multicolumn{2}{c}{ Kelas } \\
\cline { 2 - 3 } & Eksperimen & Kontrol \\
\hline Rata-rata & 72,11 & 64,57 \\
Tertinggi & 96 & 88 \\
\hline
\end{tabular}

\begin{tabular}{lcc}
\multirow{2}{*}{ Nilai } & \multicolumn{2}{c}{ Kelas } \\
\cline { 2 - 3 } & Eksperimen & Kontrol \\
\hline Terendah & 56 & 48 \\
Varian & 83,64 & 96,13 \\
Standar & 9,15 & 9,80 \\
deviasi & & \\
\hline
\end{tabular}

Berdasarkan data pada Tabel 3 terlihat bahwa terdapat pebedaan yang cukup besar antara kelas eksperimen dan kelas kontrol, hal ini mengindikasikan bahwa pemberian materi menggunakan model pembelajaran berbasis masalah dan model pembelajaran konvensional dengan metode ceramah memberikan efek positif terhadap hasil belajar fisika siswa. Sebelum melakukan uji hipotesis, terlebih dahulu dilakukan uji homogenitas dan uji normalitas. Setelah melakukan uji homogenitas, didapatkan bahwa nilai $F_{\text {hitung }}<F_{\text {tabel }}$ sehingga data yang akan diuji hipotesis dinyatakan homogen. Sedangkan mengenai uji homogenitas, didapatkan nilai $\chi_{\text {hitung }}^{2}<\chi_{\text {tabel }}^{2}$ sehingga disimpulkan bawhwa data yang akan diuji normal dan homogen selanjutnya dilakukan uji hipotesis data kelas eksperimen dan kelas kontrol. Berikut adalah tabel hasil uji hipotesis kelas eksperimen dan kelas kontrol

Tabel 4. Uji Hipotesis Post-test Kelas Eksperimen dan Kontrol

\begin{tabular}{lccccc}
\hline \multicolumn{1}{c}{ Kelas } & Jumlah Siswa & Rata-rata & Varians & $\boldsymbol{t}_{\text {hitung }}$ & $\boldsymbol{t}_{\text {tabel }}$ \\
\hline Eksperimen & 36 & 72,11 & 83,64 & 3,42 & 1,99 \\
Kontrol & 35 & 64,57 & 96,13 & & \\
\hline
\end{tabular}

Berdasarkan data di atas terlihat bahwa $t_{\text {hitung }}>$ $\mathrm{t}_{\text {tabel. }}$ Pada taraf kesalahan 5\% dan derajat kebebasan $\mathrm{dk}$ $=69$, nilai $t_{\text {tabel }}$ adalah 1,99. Hasil perhitungan $t_{\text {hitung }}$ menggunakan rumus uji t-polled varians didapatkan 3,42. Dari data tersebut $t_{\text {hitung }}>t_{\text {tabel }}$ yaitu 3,42>1,99 sehingga dapat disimpulkan bahwa $\mathrm{H}_{\mathrm{o}}$ ditolak dan $\mathrm{H}_{\mathrm{a}}$ diterima. Hal ini sejalan dengan hasil penelitian Susanto [15] bahwa model pembelajaran berbasis masalah berpengaruh terhadap hasil belajar siswa.

Ada beberapa faktor yang menyebabkan model pembelajaran berbasis masalah berpengaruh terhadap hasil belajar, model pembelajaran berbasis masalah 
memberikan kesempatan kepada siswa untuk lebih aktif dalam pembelajaran dan kemudian akan mempengaruhi hasil belajar, terlebih lagi untuk menyelesaikan permasalahan yang disediakan dalam proses pembelajaran melalui kegiatan praktikum. Hal ini tentunya memberikan pengaruh terhadap hasil belajar fisika siswa yang dapat dibuktikan dengan nilai ratarata posttes kelas eksperimen yang lebih tinggi dari kelas kontrol.

Pada awal pembelajaran siswa dikelas eksperimen diberi permasalah dalam Lembar Kegiatan Siswa (LKS) yang berkaitan dengan materi listrik dinamis yang akan diajarkan. Permasalahan tersebut dapat membangkitkan keingintahuan siswa terhadap materi yang akan dipelajari. Terkait masalah yang diberikan pada pembelajaran tersebut, siswa dituntut untuk membuat hipotesis (jawaban sementara) sesuai dengan kemampuan awal yang siswa miliki. Setelah membuat hipotesis, siswa akan melakukan percobaan atau eksperimen untuk membuktikan hipotesis yang siswa buat pada permasalahan awal yang diberikan.

Data dari hasil eksperimen yang siswa peroleh selanjutnya diolah untuk menjawab pertanyaanpertanyaan yang telah tersedia dalam lembar kegiatan siswa (LKS). Terkait pertanyaan ini siswa dituntut untuk berdiskusi dengan teman kelompok untuk mencari jawaban berdasarkan data yang diperoleh, sehingga siswa dapat bertukar informasi. Setelah itu hasil eksperimen dan diskusi yang sudah dilakukan akan disampaikan oleh salah satu anggota kelompok di depan kelas dan ditanggapi oleh kelompok lain. Penyampaian hasil eksperimen dan diskusi kelompok ini memberikan kesempatan kepada siswa untuk saling bertukar informasi antar kelompok. Peneliti dapat membantu memperbaiki dan menambahkan kesimpulan pada setiap kelompok sehingga siswa mendapatkan tambahan pengetahuan terkait masalah yang disajikan di awal pembelajaran

Berdasarkan uraian di atas, model pembelajaran berbasis masalah dapat mengaktifkan siswa melalui kegiatan pemecahan masalah. Model pembelajaran ini menuntut siswa untuk bekerjasa sama dalam kelompok. Pada model pembelajaran berbasis masalah kelompokkelompok kecil siswa bekerja sama memecahkan suatu masalah yang telah disepakati oleh siswa dan guru [4].

Pemberian perlakuan dilakukan selama tiga kali pertemuan dengan siswa, pertemuan pertama mengenai hukum Ohm, pertemuan kedua mengenai rangkaian seri dan paralel dan pertemuan ketiga mengenai hukum Kirchoff. Proses pembelajaran terjadi selama 90 menit. Pada pertemuan pertama siswa masih kurang aktif dalam mengajukan pertanyaan dan siswa juga belum terlatih dalam menggunakan alat-alat eksperimen sehingga guru perlu memberikan bimbingan. Namun pada pertemuan selanjutnya menunjukkan hasil yang berbeda, siswa terlibat aktif dalam kegiatan pembelajaran dan siswa juga mampu menggunakan alat ekperimen dengan baik.

Pada model pembelajaran langsung, pembelajaran didominasi oleh guru, siswa tidak dihadapkan dalam melakukan eksperimen sehingga selama kegiatan pembelajaran guru berperan sebagai penyaji informasi. Perbedaan pemberian model pembelajaran ini bertujuan untuk mengetahui model pembelajaran yang lebih cocok pada materi listrik dinamis untuk meningkatkan penguasaan konsep fisika siswa.

Pada pertemuan kelima siswa pada kedua kelas diberikan post-test. Nilai post-test inilah yang kemudian diolah untuk menguji hipotesis yang telah dibuat, apakah $\mathrm{H}_{0}$ ditolak atau diterima. Hasil post-test menunjukkan peningkatan nilai yang signifikan baik pada kelas eksperimen maupun kelas kontrol. Hal ini terlihat dari rata-rata hasil post-test. Rata-rata untuk kelas eksperimen dan kelas kontrol berturut-turut adalah 80,57 dan 58,53. Hal ini menunjukkan bahwa pemberian perlakuan pada kedua kelas memberikan pengaruh yang baik. Namun, selisih nilai rata-rata pada kelas eksperimen dan kelas kontrol terbilang cukup jauh, hal ini menunjukkan bahwa pemberian perlakuan menggunakan model pembelajaran berbasis masalah lebih baik daripada menggunakan model pembelajaran langsung dengan metode ceramah pada materi listrik dinamis.

Model pembelajaran ini beerfokus pada bagaimana siswa dapat menyelesaikan masalah, bukan pada bagaimana guru menyampaikan materi pembelajaran. Dalam pembelajaran berbasis masalah, siswa bekerjasama dalam kelompok dan melakukan diskusi dengan anggota kelompoknya sehingga terjadi pertukaran pikiran yang dapat membangun penyelesaian masalah.

Penerapan model pembelajaran berbasis masalah ini tentu saja memiliki beberapa hambatan. Hambatan-hambatan yang terjadi ini tentu saja akan mempengaruhi hasil belajar siswa. Berikut adalah beberapa dari masalah tersebut, yaitu jumlah siswa didalam kelas yang sangat banyak sehingga cukup sulit untuk mengatur siswa tersebut, selanjutnya waktu untuk melakukan pembelajaran (ekperimen) masih dirasa kurang, minimnya penyediaan alat-alat praktikum pada laboratorium sekolah menyebabkan siswa harus bergantian saat menggunakan beberapa alat praktikum.

\section{KESIMPULAN}

Berdasarkan rumusan masalah, hasil penelitian, analisis data, serta pembahasan maka dapat disimpulkan bahwa terdapat pengaruh model pembelajaran berbasis masalah terhadap hasil belajar fisika siswa kelas $\mathrm{X}$ SMAN 2 Praya Tahun Ajaran 2015/2016.

Saran yang dapat diberikan berdasarkan pada hasil penelitian adalah sebagai berikut: 
1. Mengingat dari hasil penelitian ternyata pembelajaran menggunakan model pembelajaran berbasis masalah dapat meningkatkan pemahaman konsep dan komunikasi matematis siswa. Dengan demikian alangkah baiknya jika model pembelajaran berbasis masalah digunakan dalam pembelajaran.

2. Berpangkal dari hasil penelitian, pembelajaran disekolah hendaknya lebih menitik beratkan pada pembelajaran yang berorientasi pada siswa, yang menuntut siswa untuk belajar mandiri dan mempunyai kesempatan untuk aktif dalam proses pembelajaran, salah satunya adalah dengan menggunakan model pembelajaran berbasis masalah

3. Penyajian soal-soal rutin sebaiknya dikurangi, alangkah baiknya jika siswa-siswa disekolah dibiasakan menyelesaikan permasalahan-permasalahan yang dapat mengembangkan kemampuan berpikir mereka serta dapat menjadikan pengetahuan tersebut menjadi lebih bermakna, dalam arti berguna bagi kehidupannya.

4. Bagi penelitian yang serupa diharapkan dalam pemilihan masalah yang diajukan sebaiknya masalah yang relistis dan menantang, agar siswa termotivasi dalam menyelesaikan masalah tersebut.

\section{DAFTAR PUSTAKA}

[1] Herman, Tatang. 2007. Pengaruh Model Pembelajaran Berbasis Masalah Untuk Meningkatkan Kemampuan Berpikir Matematis Tingkat Tinggi Siswa Sekolah Menengah Pertama. Educationist No. 1 Vol. 1 Januari 2007.

[2] Setiono, E.F 2010. Penggunaan Problem Based Learning Dalam Pembelajaran Fisika Melalui Metode Demonstrasi Dan Diskusi Ditinjau Dari Motivasi Belajar Siswa Terhadap Prestasi Belajar Siswa di SMA. Skripsi. Universitas Sebelas Maret Surakarta.

[3] Nurqomariah., Gunawan., dan Sutrio. 2015. Pengaruh Problem Based Learning dengan Metode Eksperimen terhadap Hasil Belajar IPA Fisika Siswa Kelas VII SMP Negeri 19 Mataram Tahun Pelajaran 2014/2015. Jurnal Pendidikan Fisika dan Teknologi. Vol. 1. No. 3, hal. 173-179.

[4] Trianto 2009. Mendesain Model Pembelajaran Inovatif-Progresif: Konsep, Landasan, Dan Implementasinya Pada Kurikulum Tingkat Satuan Pendidikan (KTSP). Jakarta: Kencana

[5] Rusman. 2010. Model-Model Pembelajaran Mengembangkan Profesionalisme Guru. Jakarta: Rajawali Pers.

[6] Wijaya, W., Lasmawan, W., dan Suastra, W. 2005. Pengaruh model pembelajaran berbasis masalah terhadap hasil belajar IPA ditinjau dari minat siswa terhadap pelajaran IPA pada siswa
SD di gugus IV kecamatan manggis. e-Jurnal Program Pascasarjana Universitas Pendidikan Ganesha Program Studi Pendidikan Dasar. Vol. 5 tahun 2015.

[7] Abidin, Y. 2014. Desain Pembelajaran dalam Konteks Kurikulum 2013. Bandung: PT Refika Aditama.

[8] Gayatri, I. G. A. S., Jekti, D. S. D., \& Jufri, A. W. (2013). Efektifitas pembelajaran berbasis masalah (PBM) dan strategi kooperatif terhadap kemampuan menyelesaikan masalah dan hasil belajar kognitif biologi ditinjau dari kemampuan akademik awal siswa kelas X SMA Negeri 3 Mataram. Jurnal Pijar Mipa, 8(2).

[9] Setyowati, M., Endardo, D., dan Prihadi, S. 2013. Desain Model Problem Based Learning dengan Metode Diskusi dan Insiden Ditinjau dari Kualitas Proses dan Hasil Belajar Geografi pada Kompetensi Dasar Hubungan Manusia dan Lingkungan Akibat Dinamika Atmosfer. Skripsi. Universitas Sebelas Maret Surakarta.

[10] Arends. Richard L. 1997. Classroom Instruction And Management. New York: The Mc GrawHill Companies.

[11] Wahyuni, S, dan Widiarti, N. 2010. Penerapan Pembelajaran Berbasis Masalah Berorientasi Chemo-Entrepreneurship Pada Praktikum Kimia Fisika. Jurnal Inovasi Pendidikan Kimia FMIPA Universitas Negeri Semarang. Vol.4, No.1, 2010, hal. 484-496.

[12] Sahidu, C. 2013. Penilaian Hasil Belajar. Mataram: Arga Puji Pres Mataram Lombok.

[13] Suprijono, A. 2013. Cooperative Learrning. Surabaya: Pustaka Pelajar.

[14] Anderson, L.W., Krathwohl, D.R. 2001. A Taxonomy for Learning, Teaching, and Assessing: A Revision of Bloom's Taxonomy of Educational Objectives. New York: Longman.

[15] Susanto, D., Sutrio., dan Wahyudi. 2015. Pengaruh Pembelajaran Berbasis Masalah melalui Metode Eksperimen Terhadap Keterampilan Proses Sains Fisika Siswa SMA Negeri 1 Selong Tahun Pelajaran 2014/2015. Jurnal Pendidikan Fisika dan Teknologi. Vol. 1. No. 3, 161-165. 